\title{
Beyond Inclusion: Non-monogamies and the Borders of Citizenship
}

\author{
Pablo Pérez Navarro ${ }^{1}$
}

(C) Springer Science+Business Media New York 2016

\begin{abstract}
This paper aims to understand the extent to which monogamy operates not only as a constitutive element of marriage-like institutions but also as a metajudicial source of frequently overlooked forms of state violence. Drawing on the case of the Spanish law, it explores the privilege-driven logic that regulates the access to a complex set of economic benefits and legal protections, including immigration related rights, in order to show the extent to which monogamy is part of the grounding structure of an exclusionary constitutional citizenship. In addition, drawing on semi-structured interviews held with Spanish poly activists and biographical interviews held with LGBTQ non-monogamous people, it offers a view of non-monogamous communities as paramount spaces of resistance when it comes to re-imagining the relationship between the state and the intimate realm, beyond the mere inclusion of poly and other non-monogamous intimate relationships in certain pieces of legislation.
\end{abstract}

Keywords Non-monogamies · Polyamory · Law · LGBTQ · Citizenship

I'm not included in most legislation these days, but me and my people, we're the ones they'd want to legislate against.

Kate Bornstein

The following discussion results from three intersecting lines of inquiry. The first, drawing on the case of Spanish law, aims to understand the extent to which

Pablo Pérez Navarro

pabloperez@ces.uc.pt

1 Researcher at Centre for Social Studies, Colégio de S. Jerónimo, University of Coimbra, Largo D. Dinis, Apartado 3087, 3000-995 Coimbra, Portugal 
monogamy operates not only as a constitutive element of marriage-like institutions and certain pieces of legislation but also as a meta-judicial framework of the legislative system. The second explores the effects of the monogamously structured legal framework in the privilege-driven logic that regulates the access to a complex set of economic benefits and legal protections, including immigration related rights, in order to show the extent to which monogamy is part of the grounding structure of the exclusionary constitutional citizenship. The third attempts to offer a view of non-monogamous communities as paramount spaces of resistance when it comes to re-imagining the relationship between the state and the relational diversity inherent in the intimate realm, far beyond the mere inclusion of poly and other nonmonogamous intimate relationships in certain pieces of legislation. This final line of inquiry radically calls into question the liberal narrative that conceives social progress in the arena of sexual diversity as a linear process of increasing formal recognition by connecting the dots between heteronormative marriage, gay and lesbian marriage and, finally, plural marriages.

This essay draws on semi-structured and biographical interviews carried out within the framework of the project entitled INTIMATE-Citizenship, Care and Choice: The micropolitics of intimacy in Southern Europe. It includes those held with poly activists, experts on polyamory and anti-discrimination law, in addition to LGBTQ polyamorous and other LGBTQ non-monogamous people. The former consists of seven semi-structured interviews and, the latter, of five in-depth biographical interviews using the narrative interpretive method (BNIM). I am deeply grateful to all participants for having generously shared their time, thoughts and personal experiences.

\section{Intimate Privilege and the Couple Norm}

The Spanish Constitution recognizes the right of persons to get married within the terms (forms of marriage, age-related issues, rights and duties, etc.) established by the Civil Code. ${ }^{1}$ This constitutional reference elevates married couples, making them a specially protected social unit, over any other form of partnership including de facto unions. The Constitution also establishes that 'the family' is entitled to "social, economic and juridical protection". ${ }^{2}$ Although there is no explicit definition of what exactly constitutes a family in the Spanish legislation-nor a unified family law (García Presas 2010: p. 240) — this statement institutes a crucial difference between "marriage" and "family", opening room for diverse interpretations of the family in legal terms. ${ }^{3}$ Hence, judicially speaking, "filiation links" and "parenting cohabitation" tend to define what constitutes a family, rather than civil status (Sieira and Aranda 2011) and, as a result, the nuclear family (understood as a social unit

\footnotetext{
${ }^{1}$ Constitución Española, Título I, Capítulo II, Art. 32.

2 Constitución Española, Título I, Capítulo III, Art. 39.

3 A difference that marks an advantage over other countries that, like Spain, are marked by the weight of deeply rooted catholic traditions, such as Italy, whose constitution defines "family" as a "natural society based on marriage" (Constitution of the Italian Republic, Tit. II, Art. 29).
} 
that includes parents and children), almost saturates the legal concept of the family in practice (García Presas 2010: p. 239). Still, the lack of a concrete definition of the concept, in addition to its constitutional distinction from marriage, opens the door to the potential struggles in store for individuals when obtaining legal protection for family structures beyond the monogamous nuclear family.

Despite this potentially inclusive constitutional difference, the 'couple norm' (Roseneil et al. forthcoming) shaped by marriage and de facto unions enjoys a wide range of state protections, as part of the "intimate privilege" (Rambukkana 2015: p. 29) of those who fit in it. Not only are filiation rights strictly monogamous, but marriage is still the easiest way (and especially in the case of lesbian parenting), to get children's filiation rights recognized for both mothers without having to deal with the complexities of a co-adoption process. ${ }^{4}$ Filiation problems aside, marriage enjoys important tax benefits when compared with that of single people or, for that matter, with any other form of partnership. For example, only married couples can submit a joint tax return, including both partners and children in the family unit. ${ }^{5}$ Economic privileges also cover the following: the security provided by the economic regimes of marriage, the strict regulation of alimony pensions in cases of separation or divorce, access to survivor pensions (Ministerio de Empleo 2014) and protections of inheritance rights (only in marriages where the survivor has full inheritance rights in the absence of a will, with inheritance taxes being lower for marriages in most Spanish autonomous communities), ${ }^{6}$ tax benefits when buying or selling a house, ${ }^{7}$ and advantages in access to state housing. The regulations on access to state housing, in addition to favoring family units whose total income is lower than a given amount, give priority to divorced and separated applicants independent of income, thus representing a benefit to those who the state had once recognized under the terms of marriage-like institutions. ${ }^{8}$

Spanish labor law also includes important provisions for legally constituted couples, which range from days off from work for just-married individuals to permits that allow for mutual or self-care in stipulated moments of crisis. They include permits in case of the death of a spouse or a sibling until de second degree, ${ }^{9}$ and reductions in working hours to care for a dependent partner, ${ }^{10}$ among other situations. Similarly, although independent of labor law, certain economic protections are afforded to those who care for dependent relatives, including

\footnotetext{
${ }^{4}$ Ley 3/2007, Art. 7.

5 The national tax system recognizes yet another form of family unit for tax purposes, made up of one parent and his/her children (Agencia Tributaria 2014: p. 7).

6 There are some differences between autonomous communities in this regard. In Valencia, for example, inheritance rights are almost the same between marriages and de facto unions (for a summary of these differences, see Écija 2013).

7 Ley 35/2006, Disp. Adic. 23.

8 Real Decreto 2066/2008, Art. 1.2.

${ }^{9}$ Ley 39/1999, Cap. I, Art. 1.

${ }^{10}$ Ley 39/1999, Cap. I, Art. 2.2.
} 
specific benefits for spouses as caregivers, ${ }^{11}$ not to mention the laws that regulate who are entitled to make critical health care decisions when a patient cannot. ${ }^{12}$

The aforementioned are only some of the countless privileges granted to those who fall within the definitions and terms of legal recognition that structure marriage-like institutions, giving them precedent over all those relationships, monogamous or not, that do not. As for the mention of non-monogamies, this only occurs in the Penal Code in the form of the criminalization of bigamy. ${ }^{13}$

In the US, these kinds of provisions have been actually counted, up to '1049 automatic federal and additional state protections' according with Lisa Duggan (2004) (see also Nair 2014: p. 18; Bornstein 2014: p. 24). Without performing such a detailed count, it is clear that the Spanish law reserves an important spectrum of benefits and protections to married couples and de facto unions. To apply Cristian Klesse's words to the Spanish case, this reveals "the incapacity of current law to reflect the realities of multi-partner families or polyamorous relationships" (Klesse 2011a, b: p. 237) and, in that sense, becomes a source of monogamous privilege.

\section{Care, Non-monogamous Kinship and Reluctant Marriages}

Not surprisingly, such a variety of benefits leads many people-individuals who may or may not have any interest in the symbolic value of marriage-like institutions- to register their de facto unions or to get married. That applies to some nonmonogamous and polygamous people as well, who may be interested in protecting, in legal terms, at least part of their relational constellations (for a wider discussion on marriages within non-monogamous relational constellations, see Klesse 2007: pp. 85-95). This is precisely the case of one of the interviewees of the study, 28 -year old Jackie, who defines himself as sapiosexual ${ }^{14}$ and is the only participant in the study who was actually married. When Jackie-who has chosen a feminine nickname for anonymizing purposes despite his comfort with male pronouns and his having recently begun to question his binary male gender identity-and the woman he is married to, Kenia, decided to get married, they did so after suffering from the lack of legal protection resulting from a period of mourning. As he explains, when his father died:

It was very hard. Not only because of the obvious part which made it very hard, but also because Kenia and I were not married nor did we have a de facto union nor had we legalized our situation with the State. She had to request a personal holiday so she could take days off from work in order to assimilate what had happened. She did not have a father figure as such. Her father mistreated her both physically and psychologically (...) In my father, well, she

\footnotetext{
11 Ley 39/2006, Cap. II, Art. 14.

12 Ley 41/2002.

13 Penal Code, Tít. XII, Art. 217.

14 That is to say, as someone who finds intelligence the most sexually attractive feature (regardless of gender).
} 
had a person (...) with whom she had built a relationship that was not a father/daughter relationship but one of great mutual confidence. It was a terrible blow to her and, on top of that, to be told at work 'you cannot take a single day off'. 15

So they "reluctantly" decided to get married "in case anything happened in our family lives, we could have enough time to deal with it, to accept what had happened and to be together, to share the pain and to overcome it together". Jackie's biographical narrative is full of references to the need for building relations in general, and poly relationships in particular, on the basis of practices of mutual care (a common emphasis in the discourse of poly communities, see Klesse 2011a). It is not surprising that what triggered them to get married was precisely the will to protect care-related rights that their respective labour contracts did not cover.

When they got married, despite having already agreed on the non-monogamous character of their relationship, neither of them had been involved in other simultaneous relations. It was not until immediately following the wedding-quite literally so, considering that the first triad they established resulted from an uncommon 'wedding gift' that involved spending one night with a common friends' submissive partner-that Jackie and Kenia started to open up their relationship. When I interviewed Jackie, he and Kenia were expecting their first child and still maintaining a relationship with a third partner, who Jackie describes as being part of a ' $1+1+1$ ' horizontal triad.

As it was the case with the (monogamous) relationship between him and Kenia, Jackie emphasizes the importance of different practices of mutual care between the members of the triad. However, in this and similar cases, the exclusionary effects of the monogamous law are obvious. It does not offer any formula whatsoever for including new partners as part of an already existing relationship in order to reciprocally support any these care-related practices amongst all of them. For the third member of the relationship, there are no days-off, or any other care-related provisions possible. The position of those partners who do not possess the legal recognition that other members of the relationship enjoy is in fact a very particular one. It excludes certain partners from the set of rights and benefits enjoyed in a 'monogamous' reciprocal way by his or her partners thus reproducing the legal gap between privileged, first-class citizens and second-class ones (Richardson 2000) within non-monogamous relational structures. This gap leads not only to legal vulnerability but also, as the studies performed by Christian Klesse with the UK poly communities have shown, to "problems due to envy, resentment and insecurity among some partners who cannot or do not want to partake in the privilege of a marriage or civil partnership" (Klesse 2007: p. 93, 2011a, b: p. 237).

Not surprisingly, the exclusionary character of state-sanctioned forms of recognition alone turns marriage into an unacceptable option for many, including many polyamorous activists (Aviram 2008) even if for whatever reasons its protection could actually be useful for some of them. To a certain extent, this is the position of Alex, a 35 years old bisexual man who is raising two children with his

\footnotetext{
15 Anonymized BNIM interview with Jackie.
} 
partner of 10 years, Magdalena. Although both of them have had simultaneous relationships in the past, Magdalena was the only one who was maintaining a stable relationship with another man at the moment of the interview-although it is common for Alex to share moments of sexual intimacy with his girlfriend's boyfriend. Alex holds in great esteem the process that, departing from heterosexual monogamy, has led him to explore sexuality and relational practices beyond what he refers to as "the heteronormative framework". His approach to polyamory includes anarchist and also feminist and queer political influences. Consequently, he holds a very critical opinion on marriage-like institutions, ${ }^{16}$ and he and Magdalena are quite aware of the exclusionary effects of current marriage-like institutions over a whole spectrum of families and relationships:

[Getting married] would be like surrendering any rights to other types of union. De facto unions are not what we prefer, we do not understand why the state has to justify anything, I mean, unions should be free, we do not agree with this whole couple thing. We have a woman friend who has a boy being raised with three people, with two guys who make up the couple amongst them, and so there are three adults who take care of the boy, one of them is the [biological] father and that kind of figure is never going to be welcomed. For us, this is totally fucked up. I have another woman friend who raises her kids with three friends at their home, and they are a family. De facto unions are not a solution for all of that. If we talk about polyamory rights it is the same thing, it limits all that... fluidity in relation with having kids with someone or with having a relationship with someone. ${ }^{17}$

With great clarity, Alex reminds us that marriage and de facto unions not only impose strict limits on the formal recognition of monogamous or non-monogamous partnerships, but that that is also the way the state sanctions certain kinship ties at the expense of excluding others. This is a point which was forcefully made by Butler in the introduction to 'Is kinship always already heterosexual?', where she framed the debate over (gay) marriage in the wider discussion over the state's role in relation to the regulation of kinship (Butler 2002; see also Bornstein 2014: p. 24). There, Butler used a broad definition of kinship, understood as "a set of practices that emerge to address fundamental forms of human dependency, which may include birth, child-rearing, relations of emotional dependency and support, generational ties, illness, dying, and death (to name a few)" (Butler 2002: p. 15). By pointing to a similar conception in his reference to his friends' dissident (from monogamy) family structures, what Alex's criticism highlights is that marriage-like institutions exclude not only non-monogamous partnerships but also diverse forms of non-monogamous kinship structures. In other words, by virtue of marriage-like institutions and related pieces of family laws, kinship is also always already monogamous.

\footnotetext{
16 See Against Equality. Queer Revolution, not Mere Inclusion for a recent collection of queer criticism to LGBT activism's prioritization of the struggle for gay and lesbian marriages (Conrad 2014).

17 Anonymized BNIM interview with Alex.
} 


\section{Precariousness is the New Black}

For Alex's long-term partner, Magdalena, the exclusionary role of marriage and de facto unions is sufficient reason for not joining the privileged side of relational diversity and state-sanctioned forms of kinship. By contrast, economic precariousness nuances Alex's position. His catalyst for considering the option of getting married, in spite of his anarchist's distaste for "desiring the state's desire" (Butler 2002: p. 17) is not the acquisition of care-related rights, as in Jackie's case, but a strictly economic line of reasoning (for a very similar position of a polyamorous interviewee, see Klesse 2007: p. 89):

We are not married. We have thought about it because of the kids. I would do it for the papers. That is the only reason for which I would marry. I mean, I would not organize any party. We have talked about organizing a party because of the ten years we have spent together but, of course, I would not celebrate a wedding. Nonetheless, I would consider it in case either one of us dies... I mean, we are two quite precarious people; we work at cooperative businesses with salaries below one thousand euros. If either one of us dies, we would be left butt naked. I want us to have a widow's pension, up to may be 200 or 300 euros that can provide some support. ${ }^{18}$

Counting on this kind of economic protection can indeed be a way of ameliorating the "anxiety over precariousness" (Lorey 2011) fuelled by the impact of "the escalating precarization of working peoples in Europe" (Butler 2015: p. 68) and the "no-future" scenario which accompanies the Indignant generation, in the words of Jordi Nofre and Carles Feixa (Nofre 2013). As exemplified by Alex's reasoning, precarization is in fact one of current social forces that strives to obtain legal recognition for intimate relationships in order to grant access (even if partially) to certain economic benefits. That might be specially the case of Southern European countries where austerity measures have had the most impact, such as Spain (Castañeda 2012; Cava-Aguilar and Pino 2009).

Whatever the partial legal solutions that non-monogamous people may be willing or not to accept, finding oneself at the lower levels of Rubin's "pyramid of respectability" - in which (non)monogamy was one of the structural elementsusually implies facing a "loss of institutional support and economic sanctions" (Rubin 1989: p. 12). Of course, even the (consensual) non-monogamous relational field is subjected to an uneven distribution of intimate privileges, mainly due to intersecting "privileged logics of citizenship, race, class, sexuality, gender, and age", as Nathan Rambukkana puts it (2015: p. 38). Nonetheless, as the consistent exclusion of non-monogamies from partnership- and kinship-related rights shows, non-monogamies' lack of cultural and symbolic recognition and the material and economic inequalities it is subjected to are impossible to disentangle from each other. Borrowing the words from Butler's response to Nancy Fraser's relegation of homophobia to the cultural end of the social spectrum of oppressions, the oppression non-monogamies face has never been a "merely cultural" one (Butler 1997). On the

18 Anonymized BNIM interview with Alex. 
contrary, it entangles discriminations ranging from the arenas of political economy to the governmental administration of kinship and of filiation rights, including the protection of care-related practices and, as in the case of non-monogamous migrants (Rambukkana 2015: pp. 27,89) it also directly affects the access to mobility rights (residence permits, nationality, family reunification, and so on).

Considering the diverse material effects of the strictly monogamous legal framework of partnership-related rights, one might expect to find polyamorous or other non-monogamous groups - and even those LGBT groups that fought for equal marriages in Spain before 2005-actively engaged in the struggle for the legal recognition of non-monogamous relational diversity. ${ }^{19}$ That would also be a particularly foreseeable position if we bear in mind that, at least in the US context, more than $90 \%$ of poly people think that non-monogamous relationships should be equal to monogamous ones before the law, and two-thirds would be "open" to have their non-monogamous relationships legally recognized, if such were legal. ${ }^{20}$ However, setting aside the provision of information on specialized legal advice for polyamorous relationships by certain activist groups-such as The National Coalition for Sexual Freedom ${ }^{21}$ in the US or Golfxs con Principios ${ }^{22}$ in Spainthis kind of concerns is not, for the most part, a priority for the most visible forms of poly activism (Aviram 2008: pp. 264-265).

Spanish poly activism is no exception in this regard. Certain poly groups, such as Poliamor Madrid, even define themselves nowadays in opposition to polygamy based on "their lack of emphasis on marriage" 23 or, for that matter, on any other legal demands. As is the case in other contexts, the reasons for this apparent lack of interest cannot be "fully attributed to the non-existence or marginality of the community" (Aviram 2008: pp. 264-265; see also Barker and Langdridge 2010), but rather seem to be the result of an ambivalent stance, to say the least, toward the struggle for legal recognition. Miguel Vagalume, ${ }^{24}$ from Golfxs con Principios, sums up this ambivalent attitude by stating that "even if in certain cases it is

\footnotetext{
${ }^{19}$ Leaving polygamous marriage laws aside, Brazil is possibly the only country were some timid advances have been made for the legal recognition of non-monogamous relationships. Since 2012, when the first "poliaffective union" was regularized by a Tupa's registry office employee as a "stable relationship" a reduced number of relationships have followed the example (Liberato and Gomes 2014: p. 228).

${ }^{20}$ As the Loving More Magazine survey (2012) showed with a sample of 4062 participants. When comparing these results with Hadar Aviram's previous study (2008), Hadar Aviram and Gwendolyn Leachman make the interesting remark that a certain "politicization of multiparty marriage" has arisen in the US as a result of "the LGBT movement's same-sex marriage campaign" (Aviram and Leachman 2015: p. 308).

${ }^{21}$ See https://ncsfreedom.org/.

${ }^{22}$ A collective named after The Ethical Slut, dealing with non-monogamies but also other communities: "Golfxs promotes a positive approach to non-conventional sex -polyamory, swinging, BDSM, kink, LGBT and queer-through publications, activities and services". See http://www.golfxsconprincipios. com/en.

${ }^{23}$ See http://www.poliamormadrid.org/stories/que-es-el-poliamor.html.

${ }^{24}$ Miguel Vagalume is the translator to Spanish of well-known books on polyamory and nonmonogamous relationships, such as The Ethical Slut. A Practical Guide to Polyamory, Open Relationships and Other Adventures (Easton and Hardy 2009).
} 
convenient to achieve certain legislative objectives (unions, filiations, family health care insurance...) at this moment the legal recognition of this kind of relationships is not a priority in these communities. (...) One does not escape one corset to fit into another one" ${ }^{25}$ In a similar vein, non-monogamies and anti-islamophobia activist Brigitte Vasallo ${ }^{26}$ highlights the dangers of reducing non-monogamies' transformative potential to a struggle for any specific set of legal achievements:

[The struggle for legal recognition is] A work that needs to be done, but let's see in what way it is done. Let us see if the law becomes a medium, not a pact with 'shitty reality'. Let us see if we are going to demand marriage between more than two just as a survival tool (in order to obtain recognition of children raised between more than two, to be allowed to visit your partners at the hospital, and so on), or if that is going to be an end in itself and we are going to settle for that. ${ }^{27}$

Even though there are no collective demands as such coming from polyamorous groups (yet), some activists perceive the struggle for legal recognition as a possible development of a poly community that would have had other priorities, such as opening up supportive meeting spaces and increasing the social visibility of polyamory. For example, Cuca, who was recently one of the organizers of Poliamor Madrid - the biggest group in the capital devoted solely to polyamory which brings together more than one hundred people in its monthly meetings-explains that the organizing team from Poliamor Madrid "understand that there is a need for a law, for a much more flexible law", ${ }^{28}$ especially in relation to poly families with children. Aphra Ben, an activist in a former and more activist-oriented phase of the same group, ${ }^{29}$ describes this need by stating:

We need more debate on and awareness of this not being a temporary phase 'when you are a student or have just gotten divorced'. It can be for some people, it is their right and that is just fine, but this cannot just stop there. It is necessary to integrate this reality into the legal system, maternity and paternity, care-related issues, economy and legal rights. ${ }^{30}$

When considering the relationship between non-monogamies and the law, it is important to keep in mind that, even if we were to consider only 'poly style' nonmonogamous relationships, we are not referring to any sort of sociological novelty. Some of the interviewees' recourse to different non-monogamous traditions serves to remind us precisely of that. For example, Toy, a 36-year old bisexual woman, constructed her personal approach to non-monogamies through a long trajectory from the BDSM community (which approaches non-monogamies in their own

\footnotetext{
${ }^{25}$ Expert interview with Miguel Vagalume.

${ }^{26}$ For an overview of her work on both fronts, visit http://perderelnorte.com/.

27 Expert interview with Brigitte Vasallo.

28 Expert interview with Cuca.

29 Which was active throughout the year 2010. That was the first time that a poly group participated in the LGBTQ pride, both in the "official" March and the queer, "alternative" one which was perceived by the group as a "better protest space" (Polyamoria 2010).

30 Expert interview with Aphra Ben.
} 
terms) to the polyamorous one. Mandarina, age 33 and also bisexual, makes use of the tradition of 'free love' revised through an anarcho-feminist lens, and likes to quote Emma Goldman when expressing her own points of view. In a similar way, Alex frames his approach to non-monogamies with anarchist and feminist politics whereas Daniel, 28 years old and pansexual, links his Mozambican boyfriend's conception of polyamory with his polygamous family background.

These kinds of cultural references have nothing exceptional in their relationship with polyamory 'as such'. For example, some authors consider 'polyamory' as "the most common term used by contemporary anarchists to describe their nonmonogamous relationship structures" (Portwood-Stacer 2010: p. 484; my emphasis). The Ethical Slut made clear in its very introduction that "people have been succeeding at free love for many centuries-often quietly, without much fanfare" (Easton and Hardy 2009: p. 3; my emphasis). BDSM communities tend to consider monogamy to be a particular option between a wide spectrum of relational possibilities (Sheff and Hammers 2011) - if not as a particular sexual kinkwhether or not recurring to polyamory as a complementary approach to their own way of 'doing' non-monogamy (e.g. Kaldera 2010). Other sexual counterculturesnotably the swinger community-draw on certain forms of non-monogamy as a fundamental part of what distinguishes them as a specific community.

As for polygamy, Nathan Rambukkana has recently discussed the place it occupies in the field of contemporary non-monogamies without eschewing its heteronormative character (Rambukkana 2015: p. 15) nor accepting the "overdetermined", reductive narrative that grounds the legal and social exclusion of polygamy in most western countries, such as Canada (2015: pp. 77-112). In a similar vein, Brigitte Vasallo has defended the need to engage in a productive dialogue between different approaches to non-monogamies and convincingly exposed the islamophobic assumptions grounding hegemonic depictions of polygamy in western societies-including those coming from polyamorous communities (Vasallo 2015).

That said, in a communitarian sense, polyamory is the form of non-monogamy that has been gaining visibility at a greatest pace over the past few years in Spain. More than ten years have already passed since the formation of the first mailing list and, a bit later, the first group devoted to polyamory in Madrid. Nowadays, poly groups proliferate in different Spanish cities, such as Barcelona, Murcia, Valencia or Zaragoza, among others; a non-monogamous block marched in the streets of Barcelona at last year's LGBTQ pride, ${ }^{31}$ and it is increasingly common to find polyamory-related news in the media. Books of reference for polyamorous communities, such as The Ethical Slut (Easton and Hardy 2009) and Opening Up (Taormino 2008), have been recently translated into Spanish. ${ }^{32}$ Barcelona annually hosts a major international poly event, OpenCon Catalonia, ${ }^{33}$ and Madrid's poly

\footnotetext{
31 Whose manifest can be found at https://docs.google.com/document/d/1KVD91Je-BB10vqC04dc9UdvpxQ719B-ZZk3OA51AxY/edit. During the final revision of this article, yet another nonmonogamous block participated in Madrid's queer, alternative pride March (El País 2016).

32 Both by Miguel Vagalume, who is also the organizer of Golfxs con Principios.

33 http://openconcatalonia.wordpress.com/.
} 
group, Poliamor Madrid, brings together more than one hundred people in their monthly meetings. As Cuca explains, "there has been a boom" in polyamory's visibility, partly due to "the media appearances of famous polyamorous people". In the ironic words of Brigitte Vasallo-whose articles on non-monogamies in different media and her \#occupylove ${ }^{34}$ workshops have also contributed to the visibility of non-monogamies-, polyamory has become "the new black" (Vasallo 2014).

In this rapidly changing scenario in which precariousness has also become the new black, and as Alex's longing for state economic protections reminds us, it is probably not too bold to assume that legal struggles demanding economic protections and filiation rights for diverse non-monogamous relations are poised to become increasingly common in Spain. So far, however, the only precedents of struggles for the recognition of non-monogamous relationships in Spain have come from polygamous families. For that reason, the courts' responses to their demands deserve special attention: they are crucial to understanding the extent to which monogamy is not only the source of a certain set of economic privileges, but also a problematic element embedded in the legislation in a dubious meta-judicial way with unpredictably violent consequences.

\section{Family Public Order and the Borders of Citizenship}

The Courts' general tendency is clear. Firstly, they deny requests for nationality from people in polygamous relationships. The basis for this rejection the tribunals argue, is that polygamy "sickens the Spanish public order" to the extent that it is based on the "inequality between men and women" and "the submission of women to men". 35 Secondly, they raise obstacles to any demands for family reunification coming from migrant polygamous families, thus typically preventing second spouses from joining the family unit and allowing only for children to be reunited only when special circumstances, mainly economic, concur (Zabala 2006). And, finally, the courts only under rare exceptions concede certain rights, such as shared widow's pensions, to the members of Spanish or migrant polygamous families (e.g. El País 2008).

As different authors have argued, these kinds of legal impediments tend to have a negative impact on the lives of the most vulnerable members of the family structure, such as the widows of polygamous families (legally married in third countries). That is, precisely on those whose unequal treatment "sickens the Spanish public order". This is quite the paradoxical situation, to say the least, which has led some legal scholars to argue that the rejection of the "inequality between men and women" implicit in the foreign, polygamous marriage law needs to be countered by the constitutional mandate to protect the family. Otherwise, the state would be effectively condemning "the successive wives and children, those who are the most unprotected subjects, thus producing intolerable results in relation with our own

\footnotetext{
34 See http://perderelnorte.com/polyamor-2/talleres-occupylove/.

35 STS 4764/2009.
} 
judicial order" (Zabala 2009: p. 299; my translation) to suffer from situations of legal abandonment.

The concept of "public order" ${ }^{36}$ appears in most, if not all, court rulings and academic essays on the legal recognition of polygamous families. It is as relevant for our concerns as it is difficult to deal with. In its strict legal sense, which is different from its commonplace use, it is said to refer to the "general order of society" as elaborated doctrinally and jurisprudentially (Belloso 1988: p. 234, cfr. Acedo 1997: p. 328) and even to "the set of principles and fundamental values of a community tending to achieve society's common good" (Acedo 1997: p. 329). Consequently, it has a strong moral and meta-judicial imprint to the point that it has been described as an instrument for the "closure of the judicial Order in the hands of juries" (Acedo 1997: p. 328) in the sense that even when it is linked to all the explicit norms which constitute the judicial system, it also surpasses them, giving them "closure" by virtue of its lack of formal, explicit content. Hence, "public order" is a liminal concept that, despite the sharp tone of its appearances in judicial sentences, is so closely linked with juries' conception of an extra-judicial order of society than it is with the text of the law itself. Not surprisingly, this moral content of the concept makes it prone to impact on family laws, to the point that some experts on Spanish family law refer to the existence of something like a "family public order" (García Presas 2010).

In a very clarifying way, in the context of an only apparently unrelated discussion, Spanish legal scholar Angel Acedo (1997) uses the very example of polygamy in order to explain that "polygamy is against 'public order' only insofar as it is a socially rejected exception considered as aberrant within a specific community at a specific historical moment" (p. 344). When we take into account that the uses of "public order" in court rulings are a direct reflection of what is considered legible as a constitutive part of a "specific community" at any historical moment, and that the result of its uses in court rulings directly affects the (monogamous) constitution of that very same community, it becomes clear that a certain circularity is involved. Rather than simply applying a technical concept, court rulings denying the demands coming from polygamous people would thus be engaged in a performative process whose own effects are said to ground those very same legal decisions, therefore repeatedly stating and self-justifying the "strictly" monogamous character of a society that maintains polygamy as its "aberrant" other.

It is certainly possible that, in the near future, the courts will reject similar claims made by non-polygamous but still non-monogamous people, in the name of similar arguments. Arguments nuanced, perhaps, by the lack of formal gender imbalances but, very possibly, ${ }^{37}$ still considering (consensual) non-monogamy at odds with most of court's interpretations of the "general order of society". As an illustration, as far as the right wing media is concerned, the rejection of polygamy is closely linked to that of polyamory. It is not by chance that this link has even served as the

\footnotetext{
36 We are referring to the 'formal public order,' which is concept defined "jurisprudentially and doctrinally and makes reference to the general order of society" (Belloso 1988: p. 234).

37 Legal Scholar María Lourdes Labaca Zabala, for example, considers monogamy to be "an integral element of the public order" (Zabala 2009).
} 
basis for a specifically Spanish post-equal marriage version of the already classical "slippery slope" arguments against gay and lesbian marriages (that is, the habit of linking the recognition of non-heterosexual marriage as a path leading to the recognition of whatever other "abhorrent" relational practices, notably polygamy; see Aviram 2008; Cardoso 2014; Emens 2004; Myers 2009). In what is possibly one of the best examples of this kind of connection, the journal Alerta Digital published, no less than eight years after the recognition of gay and lesbians' right to marry in Spain, an article warning that the risk of such recognition could lead to that of polyamorous relationships, along with "a myriad of forms of relationships including polygamy" (Alerta Digital 2013).

Diverse as they are, it may well be the case that the most justifiable of all possible 'polyphobias' is in fact that displayed by the judges, policy makers and legal scholars. This is due to the fact that legal conflicts arising from it go much further than the debates about whether or not to grant citizenship rights ${ }^{38}$ to certain individuals or certain groups of people. As the previous discussion of judicial and meta-judicial dimensions of monogamous privilege shows, monogamy is so embedded in the Spanish legislation ${ }^{39}$ that dealing with it is not only like dealing with the 'other' of monogamy, but with that of the legislation itself.

This is where some of the most disruptive and utopian possibilities opened up by the non-monogamous relational field rely, if only because it tends to put into crisis the monogamous legal paradigm in such a way that, along with its untreatable inner heterogeneity, it may force a radical restructuring of the relationship between the state and the intimate sphere.

\section{Beyond Inclusion: A Knocking on the Door}

The turn to the state in order to fight for the recognition of certain rights appears to be an unavoidable path for certain groups of "sexual strangers", to use Shane Phelan's words (2001). The outcomes of the encounter with state politics are, however, frequently ambivalent. Gay and lesbian marriage is an obvious recent example. Its material effects, especially when they are not detached from the recognition of non-heterosexual filiation ties are indeed countless. However, they are only granted by complying with the culturally and legally loaded terms of recognition provided by the institution of marriage. For some, leading the struggle for equal rights via these kinds of homogenizing paths -by being merely included within traditional forms of state recognition without transforming or reimagining them-may not be a problem at all. While for others it might be the opposite, to the point that sometimes, in Butler's (2004) crude words, it is "the terms by which I am recognized" which, in the end, "make life unliveable" (p. 4). In addition, the very

\footnotetext{
38 For a comprehensive discussion of the literature on "intimate" and "sexual citizenship" from the point of view of non-monogamies (beyond their relation with the law as such), see especially The Spectre of Promiscuity (Klesse 2007: pp. 142-151).

39 A similar point made in a blog article that was shared in Golfxs con Principios web was one of the initial inspirations for this part of the essay: "The problem is not (has never been) the management of the assets, but the position of the spouse in a myriad of laws" (Vimes 2013).
} 
terms of recognition offered to some groups of people or kinds of relationships reinforce the unintelligibility of those excluded from the 'brand new' set of rights, being thus doomed to remain in "the irrecoverable and irreversible past of legitimacy: the never will be, the never was" (2004: p. 106).

In relation to the 'gay marriage' debates, non-monogamous relational diversity pertains to one such realm of social, legal and political unintelligibility, that is, to the field of what is "rendered invisible" or simply "unworthy to enter the political arena" (Cardoso 2014: p. 46). This sometimes is very actively so, as in the case in Portugal when a few years ago LGBT collectives tried to exclude polyamorous activism from LGBT activist spaces (Cardoso 2014; Santos 2013).

Certainly, it could be the case that no one is more comfortable with occupying these zones of unintelligibility than certain groups of non-monogamous people, at least when it is the state that is unable of recognize the way one organizes one's own intimate life. As the editors of the special issue of Sexualities on polyamory (Haritaworn et al. 2006) put it, "if people wish to claim rights, they must fit the categories of the law", which "opens up the scope for surveillance and regulation, imposing conformity on those who seek recognition through the law" (p. 17).

While I partly agree with this claim, especially in relation to the struggle for mere inclusion in traditionally oppressive institutions (such as marriage or the military), I think it somehow underestimates non-monogamies inability to "fit in the corset," to use Vagalume's words. Precisely due to its heterogeneous, untreatable diversity, non-monogamies' encounter with the law could turn out to be not only the source of unexpected, new forms of social and legal intelligibility, granting the access to rights and protections for those who are presently excluded from even being thought about, but it might also inspire a restructuring of the relationship between the state and the intimate, relational sphere, which moves toward a much more flexible relation between the law and the intimate, relational sphere. In this sense, what the struggle for non-monogamous relationships' legal recognition compels us to consider is how to force the state to find a proper answer to the question posed by Michael Warner in his 1999 criticism of the 'gay marriage' debate: "What kind of marriage are we talking about, and how might its place in the context of state regulations about sexuality be changed?" (Warner 1999: p. 122). Needless to say, the mere recognition of 'plural marriages' or any other attempt to simplify the deep challenges posed by non-monogamies to marriage-like institutions would be a very poor answer to that question.

Reflecting on gay and lesbian marriage rights after their approval in Spain, the philosopher Paco Vidarte compared its symbolic value with an ancient Chinese vase that we had just inherited from our grandmother, one that, finally, we could "crash into pieces on the floor" (Vidarte 2005). This might indeed be a promising metaphor when thinking about the relation between non-monogamies and the law, not only in the symbolic sense that Vidarte was thinking about but also for strictly pragmatic reasons. Non-monogamous and even monogamous relational diversity is far more complex than anything the mono-normative formula 'one person, one relationship, one contract' can respond to. Instead, as Lisa Duggan has argued in the US context, a much more 'flexible menu of options' would be needed (Duggan 2004). 
Given the kind of privileges and discriminations previously discussed, such a menu would have to start off by granting: equal economic and patrimonial provisions for monogamous and non-monogamous relationships (joint taxes, widow's pensions, inheritance rights, etc.); care practices-related rights in nonmonogamous relational structures (days off at work for mourning and health-related reasons, authorization to care for dependent partners, special taxes provisions when caring for a dependent partner, etc.); legal recognition for non-monogamous variations of kinship bonds (notably, recognition of filiation bonds when there are more than two parental figures) and "marriage-like" economic regimes involving more than two people. To do that without excluding asymmetrical forms of commitment between people in relationships that may or not overlap between them and that may or not be in fact 'partners' in any recognizable romantic or sexual sense, could certainly be the task for decades of the most urgent post-marriage activism to come.

We can conceive of this task as a flexibilization ${ }^{40}$ or even a complete restructuring of the relation between the state and the intimate sphere, as an assault on the privilege-driven logic of marriage-like institutions or simply as an atomization of marriage and de facto union laws. But we would still be missing something were we to conceive any of the above as a mere democratization of the access to equal rights for all citizens, regardless of their monogamous or nonmonogamous relational choices. We would still need to question the fundamental role that certain forms of state recognition play when establishing who counts as a citizen in the first place. Before concluding, let me illustrate this point with a scene described by one of the interviewees.

Dong-Sun was one of Daniel's long-term relationships. He was from South Korea and used to live in Paris, and had married a French woman in what is commonly referred to as a 'marriage of convenience' in order to be able to remain in Europe. He even stayed at his wife's house for some time, with the purpose of protecting themselves from any investigation performed by the immigration police. During that time, it was common for Daniel to spend some nights at the house of Dong-Sun's wife. One of those nights, at a late hour, they all became startled:

We were together in this double bed, and his wife slept in another bed, in her own room. At certain point, we were almost naked when suddenly someone energetically knocked on the door, and we thought it was the police. How were we going to justify their marriage when he and I were in the same bed? I really freaked out; I was already thinking... where am I going to hide? ${ }^{41}$

\footnotetext{
${ }^{40}$ As Melita J. Noël has persuasively argued, and however we concretize them, this kind of flexibilizations would need to go hand by hand with a consistent attack on the privilege-driven logic of the 'full package or nothing' conception of marriage and would be therefore linked with the project of what she calls a "progressive polyamory". One that would be not only able to deal with its inner diversityestablishing a solidaristic ethos between different non-monogamous communities-but also to develop strong coalitional bonds with other forms of relational diversity beyond the monogamous/nonmonogamous divide (Noël 2006: p. 615).

${ }^{41}$ Anonimized BNIM interview with Daniel.
} 
Fortunately, especially for Dong-Sun, it was not the police knocking the door, but a neighbour. However, this imaginary 'police knocking at the door' suffices to call the attention to the way a non-monogamous and not even heterosexual man had to comply, even if "fraudulently" so, with the terms of recognition offered by the heterosexual-at the time in France-and strictly monogamous institution of marriage. The mere fact that that was the easiest way, if not the only one, for him to obtain a residence permit highlights some of the often-ignored relationships between compulsory heterosexuality, compulsory monogamy and certain forms of state violence, such as the threat or the actual reality of forced deportation.

Had their marriage been legit and had they, nonetheless, been distributed in the bedrooms of the house as they were that night, there would have been still very good grounds for experiencing the very same fear of the police knocking on the door. One can hardly imagine a better way of illustrating the implicit violence in the right of the state "to get into your bed" (in Alex's words) than imagining the questions the immigration police could have asked about the number and the distribution of the people in the house and beds of Dong-Sun's wife. It is in that sense that the scene, despite or even thanks to being partially an imaginary one, shows the extent which the borders of citizenship are monogamously constituted, turning mono-normativity (Pieper and Bauer 2005) into an all too often overlooked source of state violence.

For some, the encounter between non-monogamies and the law might appear as simply a pleasant side effect of future developments of non-monogamous communities. However, when thoroughly considering their potential for destabilizing the historical links between monogamy and a complex set of privileges and citizenship rights, along with the unexpected effects that such an undermining of the monogamous public order would entail (no jury, for example would show an interest in the religious or cultural grounds of any concrete form of non-monogamy except for possibly openly islamophobic reasons), certain utopian possibilities stemming from this encounter with the law might start tickling our political imaginations, with the hope being that we get closer to a total reinvention of the relationship between the state and the ways we choose to relate with others.

Acknowledgements This study was funded by the European Research Council under the European Union's Seventh Framework Programme (FP/2007-2013)/ERC Grant Agreement "INTIMATE Citizenship, Care and Choice: The Micropolitics of Intimacy in Southern Europe" [338452], under the coordination of Ana Cristina Santos.

\section{Compliance with Ethical Standards}

Conflict of interest The author declares that he has no conflict of interest.

Ethical Approval All procedures performed in studies involving human participants were in accordance with the ethical standards of the national research committee and with the 1964 Helsinki declaration and its later amendments or comparable ethical standards.

\section{References}

Acedo, A. (1997). El orden público actual como límite. Anuario de La Facultad de Derecho, 12-13, 323-392. 
Agencia Tributaria (2014). Guía de la declaración de la renta 2013. Ministerio de Hacienda y Administraciones Públicas, 7. www.agenciatributaria.es. Accessed June 28, 2016.

Alerta Digital (2013). El reconocimiento del 'poliamor', ¿el siguiente paso después del 'matrimonio' gay? http://www.alertadigital.com/2013/03/21/el-reconocimiento-del-poliamor-el-siguiente-pasodespues-del-matrimonio-gay/. Accessed June 28, 2016.

Aviram, H. (2008). Make love, now law: Perceptions of the marriage equality struggle among polyamorous activists. Journal of Bisexuality, 7(3-4), 261-286.

Aviram, H., \& Leachman, G. (2015). The future of polyamorous marriage: Lessons from the marriage equality struggle. Harvard Journal of Law and Gender, 38, 269-336.

Barker, M., \& Langdridge, D. (2010). Whatever happened to non-monogamies? Critical reflections on recent research and theory. Sexualities, 13(6), 748-772.

Belloso, I. (1988). Los conceptos de orden público y seguridad ciudadana tras la Constitución de 1978. Revista Española de Derecho Administrativo, 58, 233-254.

Bornstein, K. (2014). Open letter to LGBT leaders who are pushing marriage equality. In R. Conrad (Ed.), Against equality: Queer revolution not mere inclusion (pp. 23-27). Edinburgh: AK Press.

Butler, J. (1997). Merely cultural. Social Text, 52-53, 265-277.

Butler, J. (2002). Is kinship always already heterosexual? Differences, 13(1), 14-44.

Butler, J. (2004). Undoing gender. New York: Routledge.

Butler, J. (2015). Notes toward a performative theory of assembly (p. 68). Cambridge: Harvard University Press.

Cardoso, D. (2014). My spivak is bigger than yours: (Mis-) Representations of polyamory in the Portuguese LGBT movement and mononormative rhetorics. LES Online, 6(1), 45-64.

Castañeda, E. (2012). The indignados of Spain: A precedent to occupy wall street. Social Movement Studies: Journal of Social, Cultural and Political Protest, 11(3-4), 309-319.

Cava-Aguilar, J. M., \& Pino, M. E. (2009). The Spanish revolt: Defying the crisis from below. Teaching the crisis: Geographies, methodologies, perspectives. Berlin. http://teachingthecrisis.net/thespanish-revolt-defying-the-crisis-from-below-2/. Accessed June 28, 2016.

Conrad, R. (2014). Against equality: Queer revolution, not mere inclusion. Edinburgh: AK Press.

Duggan, L. (2004). Holy matrimony! As politicians square off on gay marriage, progressives must enter the debate. The Nation. http://www.thenation.com/article/holy-matrimony/. Accessed June 28, 2016.

Easton, D., \& Hardy, J. W. (2009). The ethical slut: A practical guide to polyamory, open relationships and other adventures. Berkeley: Ten Speed Press.

Écija, A. D. (2013). Sucesiones en parejas de hecho. Mundo Jurídico. Retrieved from http://www. mundojuridico.info/sucesiones-en-parejas-de-hecho.

El País (2008). Pensiones de poligamia. http://elpais.com/diario/2008/02/17/sociedad/1203202803_ 850215.html. Accessed June 28, 2016.

El País (2016). Zasca al amor romántico. http://ccaa.elpais.com/ccaa/2016/06/30/madrid/1467308774_ 905554.html. Accessed June 28, 2016.

Emens, E. (2004). Monogamy's law: Compulsory monogamy and polyamorous existence, University of Chicago Public Law and Legal Theory Working Paper No. 58. New York University Review of Law and Social Change, 29, 277-362. http://ssrn.com/abstract=506242. Accessed June 28, 2016.

García Presas, I. (2010). El derecho de familia en españa desde las últimas reformas del código civil. Actas del I Congreso Ibero-asiático de Hispanistas Siglo de Oro e Hispanismo general (pp. 237-265). Delhi: Publicaciones digitales del GRISO/Servicio de Publicaciones de la Universidad de Navarra.

Haritaworn, J., Lin, C., \& Klesse, C. (2006). Poly/logue: A critical introduction to polyamory. Sexualities, 9(5), 515-529.

Kaldera, R. (2010). Power circuits: Polyamory in a power dynamic. Hubbardston: Alred Press.

Klesse, C. (2007). The spectre of promiscuity: Gay male and bisexual non-monogamies and polyamories. Aldersot: Ashgate.

Klesse, C. (2011a). Options of love in polyamory-elements in a discourse on multiple loving. Laboratorium, 3(2), 4-25.

Klesse, C. (2011b). Shady characters, untrustworthy partners, and promiscuous sluts: Creating bisexual intimacies in the face of heteronormativity and biphobia. Journal of Bisexuality, 11(2-3), 227-244.

Liberato, T., \& Gomes, B. (2014). The poliaffective unions today: An analysis regarding the publicizing of the private and the access to justice. Coleção CONPEDI/UNICURITIBA, 33, 227-256.

Lorey, I. (2011). Governmental precarization. European Institute for Progressive Cultural Policies. http:// eipcp.net/transversal/0811/lorey/en. Accessed June 28, 2016. 
Loving More Magazine (2012). What do polys want?: An overview of the 2012 loving more survey. http://www.lovemore.com/polyamory-articles/2012-lovingmore-polyamory-survey/. Accessed June $28,2016$.

Ministerio de Empleo (2014). Pensión de viudedad. Beneficiarios. http://www.seg-social.es/Internet_1/ Trabajadores/PrestacionesPension10935/Muerteysupervivencia/RegimenGeneral/Viudedad/index. htm. Accessed June 28, 2016.

Myers, G. A. (2009). Drawing the line: Slippery slopes, sex panics, and polyamorous marriages. ExpressO. Stetson University College of Law. http://works.bepress.com/gretchen_myers/1/. Accessed June 28, 2016.

Nair, Y. (2014). Against equality, against marriage. In R. Conrad (Ed.), Against equaility: Queer revolution not mere inclusion. Oakland: AK Press.

Noël, M. (2006). Progressive polyamory: Considering issues of diversity. Sexualities, 9(5), 602-620.

Nofre, J. (2013). Cartografías de la indignación. Ar@cne. Revista Electrónica de Recursos En Internet Sobre Geografía Y Ciencias Sociales, 169. http://www.ub.edu/geocrit/aracne/aracne-169.htm. Accessed June 282016.

Pieper M., \& Bauer, R. (2005). Call for papers: International conference on polyamory and mononormativity. University of Hamburg, 5-6 November. http://www.wiso.uni-hamburg.de/index. php?id=3495. Accessed June 28, 2016.

Phelan, S. (2001). Sexual strangers: Gays, lesbians and dilemmas of citizenship. Philadelphia: Temple University Press.

Polyamoria. (2010). Propuesta: Visiblidad del poliamor en el Orgullo 2010. http://polyamoria.blogspot. com.es/2010/05/propuesta-visiblidad-del-poliamor-en-el.html. Accessed June 28, 2016.

Portwood-Stacer, L. (2010). Constructing anarchist sexuality: Queer identity, culture, and politics in the anarchist movement. Sexualities, 13(4), 479-493.

Rambukkana, N. (2015). Fraught intimacies. Vancouver: UBC Press.

Richardson, D. (2000). Rethinking sexuality. London: Sage.

Rubin, G. (1989). Thinking sex: Notes toward a radical theory of the politics of sexuality. The lesbian and gay studies reader (pp. 3-45). New York: Routledge.

Santos, A. C. (2013). Are we there yet? Queer sexual encounters, legal recognition and homonormativity. Journal of Gender Studies, 22(1), 54-64.

Sheff, E., \& Hammers, C. (2011). The privilege of perversities: Race, class and education among polyamorists and kinksters. Psychology and Sexuality, 2(3), 198-223.

Sieira, S., \& Aranda, E. (2011). Sinopsis artículo 39, Constitución española. http://www.congreso.es/ consti/constitucion/indice/sinopsis/sinopsis.jsp?art=39\&tipo=2. Accessed June 28, 2016.

Taormino, T. (2008). Opening up: A guide to creating and sustaining open relationships. San Francisco: Cleis Press.

Vasallo, B. (2014). El poliamor 'is the new black.' Píkara magazine. http://www.pikaramagazine.com/ 2014/10/el-poliamor-is-the-new-black/. Accessed June 28, 2016.

Vasallo, B. (2015). "Dismantling monogamy, far beyond the exclusivity issue", Keynote at the 1st Nonmonogamies and Contemporary Intimacies Conference, Lisbon, 25th-27th September. http:// saladeimprensa.ces.uc.pt/?col=canalces\&id=12977\#.V5XwsTVbhqE, https://www.youtube.com/ watch?v=NZBuhUc0Zi8. Accessed June 28, 2016.

Vidarte, P. (2005). Dhivorcio y matrimonio gay. http://www.hartza.com/matrimoniogay.htm. Accessed June 28, 2016.

Vimes (2013). El matrimonio poliamor: Propuestas. Así habló Cicerón. http://asihablociceron.blogspot. pt/2013/11/el-matrimonio-poliamor-propuestas.html. Accessed June 28, 2016.

Warner, M. (1999). Normal and normaller. Beyond Gay Marriage. GLQ, 5(2), 119-171.

Zabala, M.L. (2006). El reagrupamiento familiar en el derecho español. Revista IMES de direito, 11. http://noticias.juridicas.com/articulos/45-Derecho-Civil/200505-35551026310521151.html. Accessed June 28, 2016.

Zabala, M. L. (2009). El matrimonio polígamo islámico y su repercusión en el derecho español. Revista Jurídica de Castilla y León, 18, 261-331. 